\title{
Primary Health Care from the perception of women living in a rural area
}

\author{
Atenção Primária à Saúde na percepção de mulheres residentes na zona rural \\ Atención Primaria de Salud en la percepción de mujeres residentes en la zona rural
}

Érica de Brito Pitilin', Maicon Henrique Lentsck ${ }^{2}$

${ }^{1}$ Universidade Federal da Fronteira Sul, Graduate course in Nursing, Chapecó, SC, Brazil.

${ }^{2}$ Universidade Estadual do Centro Oeste, Graduate course in Nursing, Guarapuava, PR, Brazil.

\section{ABSTRACT}

Objective: Understanding the perception of women living in a rural area about the actions and services of Primary Health Care (PHC) in a municipality of southern Brazil, which is the only one regarded as predominantly rural. Method: A descriptive study of qualitative approach, carried out with women who lived in the countryside and required health services in the 15 days prior to collection. Results: The results registered low fidelity to PHC attributes, focusing its functional axis on sickness, transforming the unit into small points of emergency care and a bureaucratic place where patients are referred to other types of services. The quality of service offered is compromised to offering quick, fragmented and unequal treatment in the rural context. Conclusion: The findings of this study highlight the need for greater efforts in order to adequate the new care model in the development of appropriate actions as designated by PHC in the rural context studied.

\section{DESCRIPTORS}

Women; Rural Areas; Primary Health Care; Rural Health Services; Perception. 


\section{INTRODUCTION}

Primary Health Care (PHC), known in Brazil as Basic Attention (Atenção Básica), has its historical basis in international discussions of social inequities and health. It is the level of care within a health system that provides the gateway to the needs and problems of the individual and their community, having first contact, longitudinality, comprehensiveness, coordination of care, family centralization and community orientation as its attributes ${ }^{(1)}$.

Changes in demographic and epidemiological profile in the country reiterate and value PHC as essential for the reorganization of health services, since the implementation of primary care is one of the most important systemic and ideological reforms of care models today ${ }^{(2)}$.

The reorganization of the care model and the internalization of health services, especially in rural areas, are themes that permeate the current prevailing public policy in the country, since it is believed that there are natural potential vulnerabilities of this population because of the existence of health problems related to poor schooling and poorer households, transport difficulties, access to health services, and medical appointments, among others ${ }^{(3-4)}$. In this line of thinking, the importance of knowing the reality of the health services of the Brazilian rural population is emphasized due to the scarcity of publications on this population group, as they represent $15.65 \%$ of the population ${ }^{(5)}$.

Therefore, knowing the reality of services includes knowing the aspects related to the organization, structure, operation and functional and geographical access of its use. By using more health services, it is believed that women can more easily overcome these questions. As the idea of care associated with women and health services tend to be socially identified as sites for women, they become relevant for the choice of this population group in research of this context ${ }^{(6)}$.

Thus, understanding the connections between women living in rural areas and health services is a necessary challenge for promoting accessible humane care, and to be able to make the search for care a daily practice without any pain or pressure. Moreover, evaluative studies that seek to measure the effectiveness and reach of health policies to the most vulnerable population groups, including women, represent a social commitment and support in building equity ${ }^{(7)}$. Currently, some research has highlighted inequalities which persist in the health assistance process under $\mathrm{PHC}$ in urban areas ${ }^{(3,8)}$. However, these processes are still developing in rural areas.

From this perspective, the current situation brings forth the need to think of health at the primary level of the population of women living in rural areas, because as important as knowing the causes and determinants of health problems is to identify and explore the feelings and reactions expressed by them when faced with the system's inequalities. By identifying the factors that might make improvements in this area, we intend to contribute to professionals, mainly in nursing, to enter new conducts and routines to meet this specific population.
The search for matching services and PHC health activities in a rural context is an element of socially relevant work and may provide support for the reorganization of the services in this context. Thus, the question is: What is the perception of women living in a rural area about the services and activities within primary health care? To answer this question, the objective of this study was to know the perception of women living in a rural area about PHC actions in a municipality in the south of the country.

\section{METHOD}

This study aimed to answer the research question with methodology selected as an exploratory, descriptive research with a qualitative approach carried out in Basic Healthcare Units (Unidades Básicas de Saúde - UBS) among women residing in the rural municipality of Prudentópolis-PR. The municipality covers an estimated population of 51,281 inhabitants, totaling 23,901 women, of whom $51.55 \%$ reside outside the urban $\operatorname{area}^{(9)}$. Moreover, it is the second largest (municipality) in the state and the only considered predominantly rural, with $53.96 \%$ of its population living in this area.

In this municipality there are 169 locations in the countryside distributed over its land area, of which 63 were the most populated. Of these, only 14 were provided with a UBS. In other units there were no other reference points for health care attention. All units were included in the study.

The nursing technician lived in the community and acted alone in each UBS, and was coordinated by a nurse stationed at the municipality headquarters. There was a Community Health Agent (Agente Comunitário de Saúde ACS) who belonged to the Program of Community Health Agents (Programa de Agente Comunitário de Saúde-PACS), also coordinated by a nurse stationed at the headquarters. Other professionals, such as doctors, nurses, nutritionists, dentists, and psychologists were part of a traveling team, where calls were offered once a week. As for the organization of the work process, the units worked from Monday to Friday from $8 \mathrm{am}$ to $5 \mathrm{pm}$, with an emphasis on fulfilling spontaneous demand.

To collect the data, each unit was numbered 1-14, and a random drawing was held to define the initial sequence of the collection order. We also held a draw for defining the choice of day (Monday to Friday) and the period (morning or evening) for which data would be collected. The data collection took place on a single day and time in each unit and was performed by two of the researchers. Both were primary care nursing coordinators of the municipality.

Data were collected in June/2014 through semi-structured interviews, using an instrument composed of two parts: the first with questions related to socioeconomic and sociodemographic characterization and related to the use of health services (for example: frequency of health care, the demand in the unit, unit operating hours, medical consultation duration, information regarding diagnosis, respect for privacy, physical examination during the consultation, satisfaction with care, among others), while the second part of the instrument contained specific issues in meeting the objec- 
tives of the study (types of care/services offered in the unit, types of care/services the unit should have according to the opinion of women and difficulty or ease of access to service).

The inclusion criteria were considered as women who sought health care in the last 15 days prior to collection and who were residing in rural areas (assuming that there was intrinsic relationship between gender and the use of health services recently). The selection of participants was completed by spontaneous demand. First, women were found from the attendance records existing in each unit from the last 15 days. We used the first appointment of the day for selection criterion. Thus, only one participant was selected in each unit. However, two participants were selected in two units due to the presence of two concurrent appointments on that day, (one concerning a medical consultation and the other a nursing consultation). Later, the women selected were contacted by the Community Health Agent (ACS) of each unit and invited to participate in the study. In case of refusal, the second appointment of the day was selected and the process started again in succession. In total, there were six refusals.

Results were subjected to content analysis ${ }^{(10)}$. This theme is a set of communication analysis techniques through systematic procedures and description of message content objectives $^{(10)}$. In the initial stage (pre-analysis), the initial reading and re-reading of the empirical material allowed for identification coding of the most significant passages; the indicators. In the second part, the codes were organized by colors and classified as they appeared in the text and were associated with the approximate meaning of the words (stereotypes and connotations). In the next stage, called the exploitation of the material, the themes that converged to a common meaning were classified in the same category, resulting in two thematic categories. Finally, the implications emerged in accordance with the assumptions of an interpretation of messages and statements.

The interviews were conducted in a location reserved at the health unit, recorded and transcribed in full after the signing of the Informed Consent Form. To maintain the anonymity of the interviewees, they were identified and coded by acronyms (E1, E2, E3, E4... on). The study was conducted in accordance with the ethical standards required by the National Health Council(11) ${ }^{(11}$ number 466/2012, being approved by the Permanent Committee on Ethics and Human Research of the Universidade Estadual de Maringá (UEM), under Protocol number 160.417/29/10/2012.

\section{RESULTS}

18 women who met the inclusion and selection criteria were interviewed according to what was described in the Methods section. Regarding sociodemographic characterization of the women, their age ranged from 18 to 57 years of age, and most of them had not completed primary education (66.6\%). The average distance between their homes and the UBS was $13 \mathrm{~km}(\delta 3.14)$ and between their homes and the urban center/area the average was $75 \mathrm{~km}(\delta 2.12)$. Regarding marital status, $14(77.7 \%)$ were married, three were single (16.6\%) and one was divorced (5.5\%). The prevalent occupation was rural peasant/worker (83.3\%), then retired (6.5\%), janitor $(6.5 \%)$ and domestic worker (6.5\%). Their income did not exceed two minimum wages and seven (38.8\%) were enrolled in Federal Government social programs. Some of the interviewed exclusively used the health services offered by the Unified Health System (Sistema Único de Saúde - SUS) (72.2\%) and five (27.7\%) had a local health plan. Six of the women were pregnant. Through the testimonies given in this study, two categories were created: Organization and use of services in the rural area/countryside and Assistance in health care and the quality of rural care.

In the context of the first category, we noticed that the development of its own activities designated by Primary Health Care (PHC) in the context studied was still a proposal to be carried out. Basic Health Units (UBS) in the communities had their functional axis based on the hospital-centered model, transforming it into small emergency care centers. Doctors seemed to have a central role in the professional attention space, seen as the main source of care among the health services. Thus, the demand for services in the unit occurred in a timely manner and when facing a possible need:

(...) abm I go to the clinic when I need to, when I have some difficulty, because the doctor comes three times a week and only sees eight people. If there is more than eight he swears. 30 people will show up and they have to go back, because they won't be seen. Now, in this case, I came because of the pregnancy right? Then, I have to go every month (E10).

\section{(...) when you need, to get a number to be seen at 8 am, you have to arrive at 6:30 am, other- wise it's impossible, and sometimes there's only 13 numbers/consultations per day, and not ev- ery day, it only works for when the doctor comes. After lunch you have to arrive at 11:30 am and you have to stand in line waiting (E9).}

Another aspect that can be seen in the organization and use of health services in the countryside was the non-participation of women in the process of planning and organizing their own care, reflected by the (mis)understanding of the type of service provided in the unit and the lack of connection with the professional there. It was noted that the most important aspect for these women was to be assured of the consultation days, regardless of other activities such as child care, prenatal care, support groups, lectures, and immunization, among others:
(...) I don't even know for sure what's avail- able but I know that the service is really very basic. It is precarious. The doctor shows up but doesn't even see 15 people, then you get there, it is crowded/full and you have to go back home. Before there was the weight of the children, now I don't know ... we do not participate, so we don't know. Just the basic stuff like bandages is done (E14). 
(...) There are doctors on Monday, Wednesday and Friday, the rest I do not know ... once there were vaccines but because I didn't participate I do not know... but what one cannot go without is the doctor, right? Because without them there is no medicine (laughs) (E10).

Also in this context, non-adherence on the part of users in actions and planned activities of an educational and community nature aimed at promoting health occurred from their own cultural characteristics and the difficulty in accessing health services in the studied population. The low credibility in preventive actions and the influence of the medicalization of health denoted a superior status to other forms of care, as can be observed by the testimonials:

\section{(...) I go when I need to ... I do not participate in other activities. Here in this community we are many, we live far away. It's hard, those who have a car come by car, but many do not, it is quite complicated for people from far away to participate in these things... It's already hard to come to consultations with the doctor (E3).}

(...) I do not participate because it is a waste of time coming to the unit to hear the nurse speak. For me to come, I have to walk $2 \mathrm{~km}$ to take a bus. It is a half an hour walk, not including the wait for service. So I prefer to only take the bus and walk if I really need a consultation or to get some medicine (E11).

As for health care and the quality of rural care from the perspective of the women studied, it was observed that health professionals acted in a fragmented way, serving more than one location in a short period of time and space. Most of the time, the service provided a challenge to the SUS in seeking comprehensive care. This eventually ended up interfering with the quality of care and displayed ineffectiveness of the system. These findings were observed in the statements below, which make up the second analytical category of the study:

The doctor who works here also works in another community, he goes back and forth. There are times when he gets to the town hall and there's no car for him to come. Then the consultation is super quick... I entered his office, but it's funny that they don't examine you, they just ask what hurts, it's this way. Anyone can treat us (E12).

\section{(...) because he has to manage all this, he doesn't even use devices/equipment, but I don't know, I think it depends on the disease as well. He sat in front of me, he just looked at me and was already prescribing some medicine. He did not even look where it was hurting or touch my foot. Some- times I wanted to say something, but I didn't have time. He handed me the prescription and I left (laughs) (E8).}

In addition, the distribution and geographical location of health facilities in rural areas was a critical point for these women and unfavorable to adhesion and establishment of health professionals. The precariousness of local services is also reflected in the discontinuity of care, again reinforcing the fragmented care:

(...) it would be good if the doctor could stay here all the time. They almost don't stay here. One comes and shortly after they leave (E7).

\section{(...) I started my prenatal care with one (doctor) that is leaving, there is another that is coming [...]. I do not know if it's because it's so far, or be- cause that's how they work, on the same day here and there. It's not good to keep changing doctors like this. (E10).}

No matter how different the reality of actions and services in the rural context was from the ideal prospects within the PHC, these women somehow had their expectations met, making them feel assisted in some way. Having a health facility around did facilitate in times of precision and need.

(...) the little we can get is helpful. From here to town it's $74 \mathrm{~km}$. When I need to, I go by bus, but when it rains the bus does not come by, it is very dangerous because only $20 \mathrm{~km}$ have asphalt. So, because it's here, if we need to check a child's fever, for example, we knock on the door there and she'll open the door and see us if necessary (E6).

(...) it's more than $30 \mathrm{~km}$ to the city. As I don't have a car I have to come here, because I can walk here. Imagine a sick person, like my mother, she has diabetes, she can't walk and she doesn't have a car, at least she can get medication here (E14).

(...) but I think ... my God, it's still good here. God knows some places are so far that they have nothing, nothing and the only way is to go to the city, sometimes having to pay a neighbor to do this favor (E2).

All the categories of this study that referred to the organization and use of services and health care, as well as the quality of rural services, have identified that there are still inequalities in the health care process within the rural context of PHC.

\section{DISCUSSION}

From the perceptions of women studied it was possible to focus on primary care in rural areas of the south, which are still not readily available in literature, thereby exposing important weaknesses for PHC effectiveness as a strategy of health care organization in the SUS. The use of services in the countryside denoted that health actions prioritized the spontaneous demand/visits to the unit, lacking in planning for the development of actions aimed at meeting programmed demand, such as therapeutic projects, community actions, health education and home visits.

In other words, there are still inequalities in the health care process within Rural PHC, with no conformity to the 
proposal for recasting of this model. Once the care model does not include the principles of SUS, assistance will continue to be individualized, focused on medicalization and healing, with low resolution and poor social impact, therefore strictly being the participation of users at certain times and spaces $^{(12)}$.

The way the rural health system was structured did not allow for adhesion to the new care model, perpetuating itself as timely and curative care assistance. Obstacles related to the organization mode of the units, the non-use of protocols for scheduling, reception and care focused on the community, in addition to missing the programmed actions and educational nature contradict the technical proposal of the $\mathrm{PHC}$, preventing the realization of its objectives and principles ${ }^{(13)}$.

The improvement of rural health must be linked to the PHC attributes which focus on the real needs of communities by addressing the cultural aspects and consulting/ involving the community in developing solutions based on evidence to be put into practice ${ }^{(14)}$. For rural women in this study, the UBS consisted only as a gateway to the health system, with them being unable to give positive feedback and becoming a bureaucratic place that transfers them to other types of services.

Faced with the sociodemographic characteristics, low income, low education level and the type of response given by local health policies, it made sense that these women value the search for medical care at the expense of educational activities. This could be observed in the testimonies of women who at no time highlighted their participation in collective or community and health promotion activities. In this sense, it reinforces the idea that the motivations that lead people residing in rural areas to seek health care are centered on the disease process ${ }^{(15)}$. It is noteworthy that the search for the care and use of health services can be influenced according to the individual health needs of sociodemographic characteristics, the availability of professional, organizational characteristics of the service, as well as geographic distinction and access between urban and rural areas ${ }^{(16)}$.

In this context, it can be inferred that access (geographical, functional, economic and cultural) to health services for women in this study did not happen easily. This difficulty was not only related to geographical issues, but also the difficulty in getting the consultation, accessibility to specialized services and cultural access as related to their reason for seeking care. In addition, the provision of services and their geographical distribution, availability and quality of human and technological resources, financing mechanisms, the care model and the information about the system are characteristics of the offer that can affect access to health services ${ }^{(17)}$.

Access to basic health services is especially reduced in rural communities, resulting in increased use of specialized services, hospital and emergency situations due to the shortage of access to other forms of health care ${ }^{(18-19)}$. But access does not guarantee that the needs are met; a practice that meets their real demands is also necessary ${ }^{(20)}$.

Although an expansion of health services has occurred in recent years, especially of what refers to basic care, poor distribution and human resource shortages still persist in rural and remote communities in the country. The movement of these professionals around these areas often does not allow the creation of a link, making them more concerned to offer a prompt response, focused on decisioncentered therapy of diseases with little exploitation of the life contexts of patients ${ }^{(21-22)}$.

For the rural women in the study, the medical reception manner revealed a rush in care, thereby compromising the quality of service, the resolution and the effectiveness of health actions. In general, the user did not complain of lack of technological knowledge in the service, but the lack of interest in them and their particular problem ${ }^{(23)}$.

Professionals who focus their intervention on sickness and the acuteness of the cases, favoring hard and procedural technologies are directly tied to a vision of the disease as a process, contradicting the guidelines and principles of $\mathrm{PHC}^{(24)}$. In this context, nursing plays a central role in the insertion of new behaviors and routines into the provision of care within the PHC in rural areas; to deal directly with the demands which arise from these women jointly, in their entirety, in addition to building an evidence-based therapeutic plan and centered on the community.

In addition, a key component of structuring policy for health systems of rural areas is centered on the training of human resources to work in these regions who are qualified and trained in family and community medicine, in resolute ways for managing the most common problems, as well as providing comprehensive and continuous care to populations living in these territories ${ }^{(25)}$. These recommendations have great potential to contribute in overcoming the ruralurban gap and to provide quality health care to this demand if incorporated into the design of policies for providing and securing professionals ${ }^{(7)}$.

According to the women in the group studied, the geographic location and the current management policy of health facilities assembled a critical and unfavorable point against adhesion and procurement of health professionals, particularly in the medical profession. The difficulty of recruitment, appointment and securing professionals to geographically remote areas reflect the high turnover of these professionals and are associated with precarious job titles, lack of appropriate qualifications, the traveling time, and lack of materials to carry out the tasks, among others ${ }^{(26)}$.

Despite the assistance offered, rural areas appear to be compromised in the context studied, yet it somehow met the expectations of the population of women who felt assisted in some way. In this context, understanding this subjective concept of proximity to the place of service and this feeling made it possible to investigate the factors associated with the assessment of UBS, and they were largely positive. This assessment should be analyzed considering multiple factors, taking into account the different individual health understandings with respect to the social, cultural, psychological and environmental situations of the women studied.

Thus, every woman has their own perception and judgment on the practice and the performance of health services required for building improvements in the restructuring of $\mathrm{PHC}$ and the chronic access problems to public health poli- 
cies that rural populations are exposed to. This social representation in health demonstrates the potential in promoting care and effective change in the health care process model to be achieved ${ }^{(27)}$.

\section{CONCLUSION}

In the group studied, it was observed that there are still inequalities in the health care process within the context of rural PHC. The actions and practices of health services denoted a mismatch between what is designed and what is really expected within the $\mathrm{PHC}$, i.e., an effective strategy in the pursuit of health promotion, disease prevention and meeting the real needs and demands of the rural population.

Transforming curative practices into collective health practices centered on the community and care production is a challenge from the perspective of the SUS in the rural health context, since these women still carry with them the cultural baggage of the doctor figure as a reference for the care and the appreciation of seeking such assistance rather than educational and community activities; this being a result of their own sociodemographic and geopolitical characteristics, and the type of response offered/given by local health policies.

The demand for services in the units occurred in a timely manner and when facing a possible need, turning the units into small points of responsiveness. For these women, UBS existed only as a gateway to the health system, a bureaucratic place where patients are transferred/referred to other types of services. The distribution and the geographical location of health facilities assembled a critical and unfavorable point unfavorable to adhesion and securing of health professionals, revealing hurried attendance and compromised the quality of service offered.

The findings point to the need to strengthen the field of management, restructuring services in care networks and ensuring access, affordability, accountability and addressing the demands and needs of the population by trained professionals to act effectively in rural communities.

Finally, it can be emphasized that the evaluation of the recorded perception did not include all social actors, which is a limiting factor to the generalization of the data. However, it should be noted that the same geopolitical and economic reality is present in many communities in the country, which entails a deeper reflection on the issues of access to health and equity for other such rural communities.

Nevertheless, ongoing studies are needed for the consolidation of the care model proposed by PHC for the rural context that will assess the prospects of managers and service providers, as well as features for the coverage and use of such services. It is hoped that this study results in information that may support actions to promote improvements and the construction of more differentiated care in the redesign of health actions in meeting the demand of rural women.

\section{RESUMO}

Objetivo: Conhecer a percepção de mulheres residentes na zona rural sobre as ações e os serviços no âmbito da Atenção Primária à Saúde (APS) em um município do sul do país, o único considerado como predominantemente rural. Método: Estudo descritivoexploratório de abordagem qualitativa, realizado com mulheres que residiam na zona rural e procuraram os serviços de saúde nos últimos 15 dias anteriores à coleta. Resultados: Os resultados registram baixa fidelidade aos atributos da APS que, ao centrar seu eixo funcional na doença, transforma a unidade em pequenos pontos de pronto atendimento e em um lugar burocrático de passagem para outros tipos de serviços. A qualidade do serviço ofertado fica comprometida ao ofertar um atendimento rápido, fragmentado e desigual no contexto rural. Conclusão: Os achados desse estudo destacam a necessidade de maiores esforços para adequação do novo modelo assistencial no desenvolvimento de ações próprias designadas pela APS no contexto rural estudado.

\section{DESCRITORES}

Mulheres; Zona Rural; Atenção Primária à Saúde; Serviços de Saúde Rural; Percepção.

\section{RESUMEN}

Objetivo: Conocer la percepción de mujeres residentes en la zona rural acerca de las acciones y los servicios en el marco de la Atención Primaria de Salud (APS) en un municipio del sur del país, el único considerado como predominantemente rural. Método: Estudio descriptivo exploratorio de abordaje cualitativo, llevado a cabo con mujeres que vivían en la zona rural y buscaron los servicios sanitarios los últimos 15 días previos a la recolección. Resultados: Los resultados registran baja fidelidad a los tributos de la APS que, al centrar su eje funcional en la enfermedad, convierte la unidad en pequeños puntos de servicio de urgencias y en un sitio burocrático de paso a otros tipos de servicios. La calidad del servicio ofrecido resulta comprometida al proporcionar una atención rápida, fragmentada y desigual en el contexto rural. Conclusión: Los hallazgos de este estudio destacan la necesidad de mayores esfuerzos hacia la adecuación del nuevo modelo asistencial al desarrollo de acciones propias asignadas por la APS en el marco rural estudiado.

\section{DESCRIPTORES}

Mujeres; Medio Rural; Atención Primaria de Salud; Servicios de Salud Rural; Percepción.

\section{REFERENCES}

1. Starfield B. Primary care: balancing health needs, services and technologies. New York: Oxford University Press; 1998.

2. Carey TA, Wakerman J, Humphreys JS, Buykx P, Lindeman M. What primary health care services should residents of rural and remote Australia be able to access? A systematic review of "core" primary health care services. BMC Health Serv Res. 2013;13:178. 
3. Barbiane R, Junges JR, Nora CRD, Asquidamini F. A produção científica sobre acesso no âmbito do Sistema Único de Saúde no Brasil: avanços, limites e desafio. Saúde Soc. 2014;23(3):855-68.

4. Duncan MS, Targa LV. Médicos para a atenção primária em regiões rurais e remotas no Brasil: situação atual e perspectivas. Rev Bras Med Fam Comunidade. 2014; 9(32):233-4.

5. Instituto Brasileiro de Geografia e Estatística. Censo Demográfico 2010: resultados gerais da amostra [Internet]. Rio de Janeiro: IBGE; 2013 [citado 2014 dez. 12]. Disponível em: http://www.censo2010.ibge.gov.br

6. Levorato CD, Mello LM, Silva AS, Nunes AA. Fatores associados à procura por serviços de saúde numa perspectiva relacional de gênero. Ciênc Saúde Coletiva. 2014;19(4):1263-74.

7. Marques AS, Freitas DA, Leão CDA, Oliveira SKM, Pereira MM, Caldeira AB. Atenção primária e saúde materno-infantil: a percepção de cuidadores em uma comunidade rural quilombola. Ciênc Saúde Coletiva. 2014;19(2):365-71.

8. Protasio APL, Silva PB, Lima EC, Gomes LB, Machado LS, Valença AMG. Avaliação do sistema de referência e contrarreferência do estado da Paraíba segundo os profissionais da Atenção Básica no contexto do primeiro ciclo de Avaliação Externa do PMAQ-AB. Saúde Debate. 2014;38(n.esp):209-20.

9. Instituto Paranaense de Desenvolvimento Econômico e Social. Perfil do Estado do Paraná [Internet]. Curitiba; 2014 [citado 2014 dez. 12]. Disponível em: http://www.ipardes.gov.br/perfil_municipal/MontaPerfil.php?Municipio=85000\&btOk=ok

10. Bardin L. Análise de conteúdo. Lisboa: Edições 70; 2011.

11. Brasil. Ministério da Saúde; Conselho Nacional de Saúde. Resolução n. 466, de 12 de dezembro de 2012. Dispõe sobre as diretrizes e normas regulamentadoras de pesquisas envolvendo seres humanos [Internet]. Brasília; 2012 [citado 2014 dez. 12]. Disponível em: http:/l conselho.saude.gov.br/resolucoes/2012/Reso466.pdf

12. Hemmi APA, Penna CMM. A construção social da estratégia saúde da família na perspectiva de usuários. Ciênc Cuid Saúde. 2012;11(2):235-42.

13. Cunha ABO, Vieira-da-Silva LM. Acessibilidade aos serviços de saúde em um município do Estado da Bahia, Brasil, em gestão plena do sistema. Cad Saúde Pública. 2010;26(4):725-37.

14. Targa LV, Wynn-Jones J, Howe A, Anderson MIP, Lopes JMC, Lermen Junior N, et al. Declaração de Gramado pela Saúde Rural nos países em desenvolvimento. Rev Bras Med Fam Comunidade. 2014; 9(32):292-4.

15. Abimbola S, Olanipekun T, Igbokwe U, Negin J, Jan S, Martiniuk A, et al. How decentralisation influences the retention of primary health care workers in rural Nigeria. Glob Health Action. 2015;8:26616.

16. Moreira JPL, Moraes R, Luiz RR. Utilização de consulta médica e hipertensão arterial sistêmica nas áreas urbanas e rurais do Brasil, segundo dados do PAND 2008. Ciênc Saúde Coletiva. 2011;16(9):3781-93.

17. Pinto JM, Gerhardt TE. Práticas avaliativas na gestão da Atenção Básica à Saúde: estudo de caso em Camaquã e Canguçu (RS). Rev Adm Pública. 2013;47(2):305-26

18. Grant R, Ramgoolam A, Betz R, Ruttner L, Green JJ. Challenges to accessing pediatric health care in the Mississippi Delta: a survey of emergency department patients seeking nonemergency care. J Prim Care Community Health. 2010;1(3):152-7.

19. Szymczynska P, Innes A, Mason A, Stark C. A review of diagnostic process and postdiagnostic support for people with dementia in rural areas. J Prim Care Community Health. 2011;2(4):262-76.

20. Brasil. Ministério da Saúde; Secretaria de Atenção à Saúde, Departamento de Atenção Básica. Acolhimento à demanda espontânea [Internet]. Brasília; 2011 [citado 2014 dez. 12]. Disponível em: http://189.28.128.100/dab/docs/publicacoes/geral/miolo_CAP_28.pdf

21. Burille A, Gerhardt TE. Doenças crônicas, problemas crônicos: encontros e desencontros com os serviços de saúde em itinerários terapêuticos de homens rurais. Saúde Soc. 2014;23(2):664-76

22. Martins LF, Laport TJ, Menezes VP, Medeiros PB, Ronzani TM. Esgotamento entre profissionais da atenção primária à saúde. Ciênc Saúde Coletiva. 2014;19(12):4739-50.

23. Santos WJ, Giacomin KC, Firmo JOA. Avaliação da tecnologia das relações de cuidado nos serviços em saúde: percepção dos idosos inseridos na Estratégia Saúde da Família em Bambuí, Brasil. Ciênc Saúde Coletiva. 2014;19(8):3441-50.

24. Bezerra PCL, Opitz SP, Koifman RJ, Muniz PT. Percepção de saúde e fatores associados em adultos: inquérito populacional em Rio Branco, Acre, Brasil, 2007-2008. Cad Saúde Pública. 2011;27(2):441-51.

25. Alameddine M, Khodr H, Mourad Y, Yassoub R, Ramia JA. Upscaling the recruitment and retention of human resources for health at primary healthcare centres in Lebanon: a qualitative study. Health Soc Care Community. 2015;38(2):1011-19.

26. Silva AS, Nogueira DA, Paraizo CMS, Fracolli LA. Assessment of primary health care: health professionals' perspective. Rev Esc Enferm USP. 2014;48(n.spe):122-8.

27. Cruz JS, Souza Junior AV, Barreto EJ, Araújo JG, Almeida MVG, Gonçalves CCT. Gestão da atenção básica no sistema único de saúde de Santo Antônio de Jesus, Bahia, 2009-2012. Rev Baiana Saúde Pública. 2014;38(1):49-66. 